\title{
APPLYING ASSOCIATION TECHNIQUE IN TEACHING EFL VOCABULARY TO THE STUDENTS IN INDONESIA
}

\begin{abstract}
This paper pointed toward examining the application of association technique in showing EFL vocabulary to the understudies. This exploration utilized a cooperative study hall activity research plan and it was carried out as cycles comprising of four significant advances: arranging, executing, noticing and reflecting. The subject of the exploration was 30 understudies in Indonesia. The instruments used to gather information were test, perception agendas, and field notes. This exploration was finished in two cycles in light of the fact that the aftereffects of the examination in the primary cycle didn't meet the rules of accomplishment. Every one of cycle involves four gatherings. The discoveries of the exploration showed that the applying of strategy in training English can build understudies' vocabulary dominance. This is appeared by the understudies' fruitful rate in cycle I was half, in Cycle II and the quantity of the understudies who got scores at any rate 6.5 or more noteworthy was $27(90 \%)$. Likewise, the understudies gave positive reaction toward the perception agenda result, in particular: eagerness, inspiration, interest, reaction, and progress. It very well may be reasoned that the association technique is successful and material in educating vocabulary.
\end{abstract}

Keywords: EFL, vocabulary, association technique

\section{INTRODUCTION}

In showing English, vocabulary assumes a significant part in building up the four language abilities, for example talking, tuning, recorded as a hard copy, and perusing. Furthermore, they are upheld by language parts like vocabulary and syntax.

English instructors in the primary school are required to be inventive to raise the understudies' learning inspiration and make them keen on learning English vocabulary. They need to utilize fascinating and fitting procedures in showing vocabulary, like singing a melody, utilizing pictures, utilizing streak cards, and utilizing affiliation strategy. 
In view of the researcher's discoveries through perception and her experience showing school, the greater part of the understudies particularly for the 6th grade understudies didn't have the foggiest idea about the essential English words dependent on the showing theme in the showing material, for example, words identified with leisure activities, food and drink, transportation, and occupation. Plus, they were as yet hard to articulate English words and to retain their significance so they wonder whether or not to impart in English. They actually experienced issues in utilizing English appropriately in both oral and composed correspondence since they need vocabulary. They had restricted words, so they discover trouble to communicate their thoughts.

In actuality, the educator's showing style and the procedure that applied by the instructor gave an incredible commitment to the condition. A few realities were discovered identified with the showing vocabulary: (1) the educator doled out to understudies to remember certain words found in the course reading or in the word reference; and (2) the instructor requested that the understudies discover troublesome words or new words at that point made an interpretation of them into Indonesian. The strategies applied by the instructor don't appear to be successful since they don't give a lot of commitment in building up understudies' vocabulary dominance. The analyst further idea that improper encouraging method applied by the educator might be the reason for the low capability of the understudies in learning English.

In this matter, the association technique with word association is one of the solutions to develop the students' vocabulary when they see something or hear some 
words. For instance, the teacher said the word 'tree' and asked the students to mention parts of the tree. The students mention them such as leaf, fruit, and branch. Therefore, this research is carried out and entitled Teaching Vocabulary through Association Technique.

\section{RESEARCH METHOD}

The researcher utilized a subjective examination led by applying homeroom activity research plan. It covered between significant components comprising of preparation, execution, perception, and reflection. These managed interaction of encouraging vocabulary through word affiliation discover in the essential understudies. Kemmis and McTaggart (1988) state: "Activity research begins with little patterns of preparation, acting, noticing and reflecting which can assist with characterizing issues, thoughts, and suppositions all the more plainly so those include can characterize all the more impressive inquiries from themselves as their work advances."

The assertion above explains that activity research is proposed to defeat the issues. They have an immediate application in the setting where the exploration is directed.

Strategy of Data Analysis

In homeroom activity research, information investigation is done to gather the information from various instruments, choosing, classifying, looking at, orchestrating, and deciphering information; it will be done in progressing repetitive interaction (McMillan and Schumacher, 1993). To approve information, the specialist utilized triangulation. Triangulation is cross plan of cross approval information acquired from 
the field. It comprised of three principle steps to investigate information; they are information assortment, information decrease and information show. It was centered around the cross check between the information got from various instruments that is utilized in research. It was pointed toward making information more exact.

\section{RESULTS AND DISCUSSION}

Examination instruments

Examination instruments were significant to acquire solid information that was significant for the analyst to dissect them. There are two benefits of getting ready exploration instruments before the scientist directed the examination; the achievement of dependability and legitimacy of the actual instruments; and the unwavering quality and the legitimacy of the information.

Solid and steady examination instruments lead the scientist to develop legitimacy and dependability of them. It is viewed as significant for the need of the analyst. In the interim, appropriate instruments will exceptionally decide the dependability and legitimacy of the information. In references to the planning on research instruments, the analyst thought about that she has the set up proper scientist instrument on the premise on research need. Besides the exploration instrument she used to gather information in agreement to the attribute of the information. It implies that the analyst has arranged proper specialist instruments before she and the associate were in real life doing the examination. She furnished exploration instruments with sorts of the information he need to acquire.

Instructional material and media 
The arrangement on instructional material and media was essential to be done before the exploration was directed. Readiness was firmly identified with educating arranging. In light of the discoveries, there were five things the specialist arranged or arranged according to instructional materials and media. They comprised of exercise plan, showing materials, educating media, assessment sheet, and scoring sheet.

The discoveries worried with instructional arrangement or arranging that were introduced in this section showed that what the analyst had done some significant arrangements before he went to the field of examination. She truly comprehended how should she dealt with make the specialist solid and steady and efficient. The activities that the scientist did in getting ready instructional materials and media were considered as one of the outcomes in doing educating action.

Getting ready for the principal cycle

The underlying undertaking for the specialist to do when she needed to start the training learning interaction of the primary cycle was to get ready exercise plan. Exercise plan contained time designation, standard skill and fundamental ability, marker for understudies' accomplishment in vocabulary class, showing targets, showing materials, showing strategy, encouraging techniques utilized by the scientist, showing assets, and assessment. To do the get ready exercise plan for instructing is an absolute necessity for an educator before she leads showing learning measure.

It is justifiable that solid and steady exercise plan will contribute a feeling of certainty for the instructor to educate. The educator will feel got from loosing course in the center of the exercise in the event that she recently coordinated exercise plan well. Thus, in light of the discoveries, the scientist built up a model of exercise plan that 
can furnish her with assurance for acceptable educating and for accomplishing instructional targets.

Different segments of exercise plan that the analyst ought to likewise consider to get ready were pointer and instructional destinations. Instructional targets were important to be built by the analyst since they have ability to know east from west to lead the specialist and the understudies to accomplish anticipated showing learning destinations. Every exercise will have at least one targets. A goal is the assertion of proposed learning results. Destinations normally portray what the understudies will actually want to do when guidance has been finished. In accordance with the assertion, the specialist built guidance destinations in regard to the language expertise in which the understudies need to reach toward the finish of the exercise. Since the examination stressed on showing vocabulary; so she indicated instructional goals on the space of the proposed expertise. Indicating instructional destinations implies building a structure of guidance and centering it to explicit objective of learning. Instructional goals ought to be unequivocally expressed in exercise intend to empower the instructor to control her showing learning cycle to be in right way. What the specialist has done in her exercise plan was she expressly expressed instructional goals and restricted them based on language expertise that she expected to improve. Additionally, instructional goals ought to be in accordance with the subject that the understudies will contemplate. In the primary cycle, the specialist served the understudies with the subject about "pastimes". In this matter, the scientist expected to incorporate one of instructional goals managing theme. So it is sensible that instructional targets ought to likewise be identified with the theme. 
To give a precise judgment about the accomplishment of the showing learning measure, the scientist expected to build markers of accomplishment. Markers should be as for instructional targets, and should be in a congruity with fundamental skill and standard capability. The markers of encouraging learning accomplishment are valuable to see whether the instructional has been accomplished. From the discoveries, it was tracked down that the specialist organized pointers of accomplishment by restricting them just in the space of educating vocabulary. Like instructional goals, markers of accomplishment was additionally orchestrated as per the subject of the exercise. The normal instructing destinations that the scientist built in the exercise plan in the main gathering were as per the following:

Before the finish of the class, the understudies can:

a. mention the significance of the things identified with leisure activities and articulate them accurately.

b. spell the things accurately. Student's participation in learning and teaching process Appraisal on instructing learning cycle ought to be comprehensively led by the specialist to empower the educator to direct an exact judgment about the interaction. All-encompassing appraisal incorporates the evaluation worries about understudies' investment in study hall communication. Understudies' cooperation should be evaluated to ensure that they are feel be valued each time they give a valiant effort. Related to evaluation on understudies' support, understudies' investment in the training learning cycle can be surveyed by utilizing gave graphs. Unmistakably to survey or to assess understudies' cooperation adds to diminish their nervousness to exercise or any very muddled study hall task. There was a slight distinction among 
Burden's and Byrd's way in noticing understudies support and the scientist's way. To survey understudies' homeroom investment, the analyst utilized perception agenda that contains three classifications, low mid, and high.

Understudy's Performance in Teaching Learning Process

Understudies' presentation in the encouraging learning measure was addressed by five parts in which the understudies were evaluated. It was by reason arranged by the specialist to see the distinction in understudies' presentation from one gathering to another. Unmistakably to survey or to assess understudies' exhibition adds to diminishing their nervousness to exercise or any very confounded study hall task.

The parts that the specialist utilized them as markers to survey understudies' presentation in the instructing learning measure are understudy's eagerness, inspiration, premium, reaction, and understudies' advancement. The five segments were painstakingly seen to ensure that the understudies have progress in study hall execution from one gathering to other gathering.

Understudies improvement

The understudies' improvement in vocabulary through letters in order cards were explored and broke down through assessment period of the showing learning measure. The analyst zeroed in on the three rules of accomplishment where she expected to examine toward the finish of cycle. To give better comprehension toward the discoveries, the aftereffect of investigation will be explained as follows:

Gatherings 1, 2, 3, and 4 in cycle I

To break down the three models of accomplishment, the scientist used affiliation procedure, perception registration, and field notes. The aftereffect of investigation 
was that from the main trial of the cycle 1 it was found there were fifteen of thirty understudies who got "great" or "excellent" score. It implied that the understudies' effective rate that got achievement level from the principal trial of cycle I had not at this point meet the rules of accomplishment. Since, the rate approach utilized recipe 15x100\%:30 = half. 15 was the quantity of understudies who got achievement capability; 30 was the quantity, all things considered, and 100 is the deviation scale. Then again, the level of study hall achievement ought to be $65 \%$ of the quantity of understudies.

In the mean time, the score of fifteen understudies more than 66. It was not delegate enough for the scientist to decide that the measures of accomplishment have been accomplished since the standards of achievement for singular understudies ought to be 66; in spite of the fact that there were fifteen understudies who got more than 65 yet the number didn't address yet all class members. In this manner, all in all, the analyst contended the models of progress will be accomplished if the greater part of understudies accomplish score 66 or over it and there are at any rate $65 \%$ from absolute understudies got achievement level. Besides, singular score anyway was to pass judgment on the understudies' accomplishment exclusively.

The understudies' interest in learning measure was recognized through homeroom exercises. Investment as a type of learning measure was dissected subjectively. The consequence of perception shows that the understudies were effectively partaking in study hall exercises.

Gatherings $1,2,3$, and 4 in cycle 2 
The aftereffect of investigation toward assessment on cycle II gathering 4 evoked the huge improvement on understudies' vocabulary. During that time test in cycle II; it was discovered that there were 27 understudies who got "achievement" capability. It implies that the quantity of understudies who got "achievement" from the second assessment of cycle II has met the standards of progress; in light of the fact that the rate approach utilizes equation $27 \times 100 \%: 30=90 \% .27$ is the quantity of understudies who get "achievement" capability; 30 is the quantity, all things considered, and 100 is the deviation scale. Since the quantity of understudies who got "achievement" capability in excess of a portion of the absolute number of understudies (90\%), so it is inferred that the models of study hall accomplishment has been accomplished.

In the interim the higher score of 27 understudies more than 66. It very well may be deciphered that it is totally sensible for the analyst to decide that the rules of progress have been accomplished since the measures of achievement for singular understudies ought to be 66 ; in addition there were 27 understudies who got at any rate 66 so the number has addressed all class members.

The critical accomplishment in cycle II was caused of the utilization of affiliation strategy and the execution of certain discoveries in appearance in cycle I, to be specific:

1. The educator needs to set the time relatively for every one of the exercises done. In this matter, the instructor set the three fundamental exercises relatively dependent on the substance of the exercises (pre-exercises 5\%, while-exercises $80 \%$, and postexercises 15\%). The pre-exercises just canvassed 5\% since in this stage the educator just did some short exercises like posing inquiries to lead the understudies to the 
subject examined. While-exercises covered the greatest measure of time since this stage is the center exercises and an opportunity to apply the affiliation strategy. What's more, the last, post-exercises covered $15 \%$ of constantly. In this stage, the educator completed three exercises, specifically: closed the material and gave the understudies support, streaked back to the past study hall action, controlled the understudies with schoolwork and recommended them to remember every one of the words that have been given.

2. When asking the understudies for turn, the instructor ought allow to specific understudies as well as others understudies relatively. The basic mix-up of an instructor in the study hall exercises is that, he/she as a rule doesn't give an opportunity relatively to the understudies. He/she simply gives chance for a specific student that he/she wanted. This treatment turns out to be exceptionally essential since it can support the understudies inspiration, interest, and consideration.

3. In clarifying the assignment or giving guidance utilizing English, the instructor expected to disclose it in Indonesian to forestall to understudies misconception. This treatment is additionally vital since not every one of the understudies comprehend what the educator have clarified and trained. In this way, subsequent to clarifying and training them, the instructor ought to affirm if they have effectively perceived. At that point, she converted into Indonesian the clarification and guidance as clear as conceivable to keep away from the understudies' misconception.

\section{CONCLUSIONS}

Vocabulary can be educated through association technique by the accompanying methodology, specifically: the educator needs to set up certain words that will be related. The educator can likewise utilize a few pictures to depict a theoretical word 
that the understudies infrequently hear or see. In the event that they experienced issues notice it in English, she allows to the understudies to specify in Indonesia, at that point the instructor interpreted the word in English and requested that the understudies retain the words. In the following gathering, prior to beginning the exercise, the educator asked a few words that have been concentrated in the last gathering to check the understudies' accomplishment.

In light of the strategies carried out above, at that point the analyst introduced the outcomes: first, the educating of English vocabulary through affiliation procedure can build understudies' vocabulary dominance particularly they ought to have more vocabulary for in any event 300 words in term of the significance and how to articulate the words. Second, by contrasting the consequence of' understudies' accomplishment in the main cycle, the understudies' accomplishment on second cycle has huge turn of events. This can be concentrated from the understudies' effective level of spelling quiz in cycle I was half be expanded to $90 \%$ in cycle II. Third, affiliation strategy can urge understudies to be dynamic to join study hall exercises. By giving a word dependent on the point talked about and requested that they partner the words, the understudies contend in responding to the inquiry, doing the errands, spelling and rehearsing to articulate the words. Furthermore, last, the understudies had positive reaction toward the utilization of association technique in learning vocabulary. This method could build up understudies' eagerness, inspiration, interest, reaction, and progress in joining the class and finishing the homeroom assignments.

\section{REFERENCES}

Albana, H. H., Marzuki, A. G., Alek, A., \& Hidayat, D. N. (2020). Cohesive Devices in Student's Writing (A Discourse Analysis on Argumentative Text). Jurnal Pendidikan Humaniora, 8(1), 6-11.

Alek, A., Marzuki, A. G., Farkhan, M., \& Deni, R. (2020). Self-Assessment in Exploring EFL Students' Speaking Skill. Al-Ta lim Journal, 27(2), 208-214.

Alek, A., Marzuki, A. G., Farkhan, M., Surahman, D., Daryanto, D., \& Febrianto, S. (2020). Computer Based Testing in Senior High School on National Examination. Indonesian Journal of Learning Education and Counseling, 2(2), 204-210. 
Allen, Virginia F. 1983. Techniques in Teaching Vocabulary. Oxford University Press, Oxford.

Arikunto. S. 1996. Prosedur Penelitian Suatu Pendekatan Praktek. Edisi Revisi. PT. Rineka Cipta. Jakarta.

Bailey, K.M. 2005. New Ways in Teaching Speaking. Mc Grow Hill, Boston.

Best, John. 1981. Research in Education. Eaglewood Cliffs, Prentice-Hall, Inc. New Jersey.

Bogdan, C.R. and Biklen, K.S. 1998. Qualitative Research in Education. An Introduction to Theory and Method. Allyn and Bacon, Boston.

Doff., A. 1993. Teach English A Training Course for Teacher. Cambridge University. New York.

Fisher, C.J., and Terry, C.A. 1997. Children's Language and the Language Arts. Second Edition. Mc. Graw-Hill, Inc. New York.

Harahap, Nasrun. 1992. Tehnik Penilaian Hasil Belajar. Bulan Bintang, Jakarta.

Harmer, J. 1991. The Practice of English Language Teaching. Longman Group UK Limited, London.

Kemmis, and McTaggart, R. 1988. The Action Research Planner. Deakin University Press, Victoria

Kuliahana, A., \& Marzuki, A. G. (2020). Repetition Technique in an EFL Speaking Class in Islamic Higher Education in Indonesia. Academic Journal Perspective: Education, Language, and Literature, 8(1), 20-28.

Lyons. J. 1971. New Horizon in Linguistics. Penguin Books Ltd. Sidney.

Marzuki, A. G. (2016a). Developing reading skill of islamic education department students through guided reading. Paedagogia: Jurnal Pendidikan, 5(2), 235-257.

Marzuki, A. G. (2017a). Applying mind mapping technique in improving english vocabulary mastery in an efl classroom. Paedagogia: Jurnal Pendidikan, 6(2), 276-293.

Marzuki, A. G. (2019). The Implementation of SQ3R Method to Develop Students' Reading Skill on Islamic Texts in EFL Class in Indonesia. Register Journal, 12(1), 49-61.

Marzuki, A. G. (2019). The Roles of School Principal Leadership in Developing English Teachers' Creativities in Palu. Al-Ta lim Journal, 26(3), 267-279.

Marzuki, A. G. (2019). Utilizing Recorded English Dialogues in Teaching English Word Stress to Islamic Higher Education Students in Indonesia. Jurnal Pendidikan Islam, 5(1), 53-64.

Marzuki, A. G., Alim, N., \& Wekke, I. S. (2018). Improving the reading comprehension through cognitive reading strategies in language class of coastal area in indonesia. In IOP Conference Series: Earth and Environmental Science, 156(1), 012050). IOP Publishing.

Marzuki, A.G. (2016b). Utilizing cooperative learning in islamic college students' classroom, IJEE (Indonesian Journal of English Education), 3(2), 123-139.

Marzuki, A.G. (2017). Developing speaking skill through oral report in an efl class in indonesia, Al-Ta'lim Journal, 24(3), 243-254.

McCarthy and Felicity. 2001. English Vocabulary in Use. Erlangga. Jakarta.

McMillan, J.H. and Schumacher, S. 1993. Research in Education. A Conceptual Introduction. Harper Collins Publisher, Virginia. 
McNiff, Jean. 1992. Action Research: Principle and Practice. Chapman and Hall, Inc., New York.

Napa, P.A. 1991. Vocabulary Development Skills. First Edition, Kanisius. Yogyakarta.

Nation, I.S. 2001. Learning Vocabulary in another Language. Cambridge University Press, Cambridge.

Sonka, A.L. 1981. Skillfull Reading a Text and Workbook for Students of English As a Second Language of America. Prentice Hall. Englewood.

Sugiono. 2007. Metode Penelitian Pendidikan. Alfabeta, Bandung.

Sutomo. 1985. Tehnik Penilaian Pendidikan. Bina Ilmu. Surabaya.

Widayati, Sri. 2002. Happy with English. Ganeca Exact. Jakarta. 